\title{
Determining the Differences in the Impacts of Factors Affecting Sovereign Credit Rating: A Case Study of Developing ASEAN and Developed Countries
}

\author{
Quynh T.P. $\operatorname{Lam}^{1 \bowtie}$ \\ Quoc T. Nam ${ }^{2}$ \\ Khoa D. Nguyen ${ }^{3}$
}

${ }^{1,2}$ Department of Economics and Business, Hoa Sen University, HCM City, VietNam Email:quynh.lamthanhphi@hoasen.edu.vn Tel:084.0772714401 'Email: trannam.sse@gmail.com Tel:0840919393940

Department of Banking and Finance, University of Finance and Marketing, HCM city, VietNam. 'Email:nguyendanglchoa6859@gmail.com Tel:0962766859

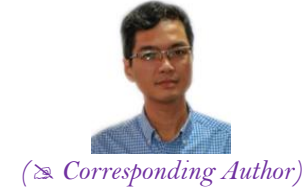

\begin{abstract}
The paper uses the ordered logit regression model on table data to determine the differences in the impact of factors affecting the sovereign credit ratings of ASEAN developing countries compared to other developed countries. The results show that the impact of the macroeconomic indicators on the sovereign credit ratings in ASEAN developing countries decreases in comparison to the impact of factors in developed countries. Besides on that, there is no difference in the impact of the factors demonstrates the efficiency of governance on sovereign credit ratings in developing ASEAN countries compared to developed countries.
\end{abstract}

Keywords: Sovereign credit rating, Ordered logit regression model, Factors affecting the sovereign credit rating, ASEAN country, Credit rating, Efficiency in government management.

JEL Classification: G24, G15, O16, F33.

\section{Introduction}

Over the past few decades, globalization has provided investors around the world many opportunities to diversify and find attractive returns from investments in various countries in the world. However, highly profitable opportunities often go along with potential risks in numerous countries. Therefore, international investors are very concerned about quantifying the level of specific risks of each country before implementing investment activities in this country. The most prestigious international credit rating organizations such as S\&P, Fitch Group and Moody's regularly publish information about the credit ratings of countries for investors to refer to in their international investment activities. Haque, Kumar, Mark, and Mathieson (1996) define sovereign credit rating as an aggregate assessment of the macroeconomic factors and the government's operating capability to evaluate the probability of government to pay due debt obligations.Fitch (2020) pointed out that a country's risk level and its credit rating are two related but separate concepts. The country's level of risk refers to the risks of implementing an investment in the country, like poor property rights protection, erratic fluctuations in taxes and official regulations, or a disturbance in the business environment. Meanwhile, the sovereign credit rating focuses on assessing the risk of insolvency of the government for the debt obligations that come due. The sovereign credit rating process of international credit rating agencies such as Fitch, S\&P or Moody's represent an analysis that combines both qualitative and quantitative assessment to determine the availability and the government's ability to discharge maturity debts. Credit rating agencies often rate countries' credit ratings on the following groups of criteria. The critical financial indicators reflecting current macro characteristics and economic prospects include GDP growth rate, net FDI inflows, inflation rate, labor unemployment rate.

The indicators reflect the ability of the government to manage and govern the economy like voice and accountability, political stability and non-violence, government effectiveness, quality of regulations, rule of law, the ability to control corruption. Fitch and $\mathrm{S} \& \mathrm{P}$ have 22 sovereign credit ratings from AAA to RD/D. Moody's equally has 21 sovereign credit ratings from Aaa to $\mathrm{C}$.

International credit rating agencies have presented the criterias and processes for evaluating the credit ratings of countries quite fully. However, some researchers have pointed out that there is a difference in the impact factors or the degree of impact of these factors on the credit ratings of developed countries compared to developing countries. Specifically, Ferri (2004) has shown the cost of collecting information for the assessment of ratings in developing countries is often much higher than in developed countries. Otherwise, macro data of developing economies are also not extremely accurate. Therefore, credit rating agencies when assessing the credit rating of developing countries are frequently based on subjective assessments of experts rather than analysis of macro data of these countries. On the other hand, research of Gültekin-Karakaş, Hisarcıklılar, and Öztürk (2011) also showed that international credit rating agencies have highly appreciated the credit rating of developed countries without regard to the significant macroeconomic indicators of these countries. Mora (2006), Kiff, Nowak, and Schumacher 
(2012) also showed that credit rating organizations apply different weights in the process of evaluating the indicators reflecting the credit rating in diverse countries. Credit rating agencies sometimes ultilize expert assessments in the credit rating process. Tennant and Tracey (2016) also showed that the threshold of raising the national credit rating level of developing countries is often higher than that of developed countries. However, Gültekin-Karakaş et al. (2011) argues the discrepancy in the credit rating of developing countries can be explained by the difference in governments' management ability to regulate the economy in developing countries compared to developed countries. In summary, the authors notice that previous studies on sovereign credit ratings do not detail the difference in the impact of factors affecting creditworthiness of developing countries compared to developed countries. On the other hand, no studies analyze in detail the factors affecting the sovereign credit rating of developing countries in the ASEAN region. Therefore, this study aims to determine the differences in the impact of factors affecting the sovereign credit ratings of ASEAN developing countries relative to developed economies. On that basis, governments of ASEAN developing countries can propose appropriate measures to improve their country credit rating. The paper is structured as follows. Section 2 presents research models, research data and analytical methods to determine differences in the impact of factors affecting sovereign credit ratings in developing ASEAN countries and other developed economies. The results of the research model are presented and analyzed in detail in section 3. The concluding section summarizes the primary results of the study and proposes recommendations to improve the sovereign credit ratings of the ASEAN developing countries.

\section{Model, Research Data and Data Analysis Method \\ 2.1 Research Model}

The research model used by the authors in this paper is the ordered logit model on table data. The ordered logit model is an extension of binary logit model. This model assumes the following latent variable form Greene (2012):

$$
y^{*}=\mathbf{x}^{\prime} \beta+\varepsilon .
$$

In which $\mathrm{y}^{*}$ represents the dependent variable but is not observable in reality. We can merely observe:

$\mathrm{y}=1$ if $\mathrm{y}^{*} \leq 1$

$=2$ if $1<\mathrm{y}^{*} \leq \mu_{1}$

$=3$ if $\mu_{1}<\mathrm{y}^{*} \leq \mu_{2}$

...

$=\mathrm{J}$ if $\mu_{\mathrm{j}-1}<\mathrm{y}^{*}$

In which: $\mu 1, \mu 2, \ldots \mu j-1$ are the thresholds calculated from the model.

$\beta$ is the regression coefficient illustrating the impact of the explanatory variables on the dependent variable.

$\mathcal{E}$ is a stochastic error term. $\mathcal{E}$ secures a rational distribution and utilizes a mean of 0 , variance of 1 .

The ordered logit model is widely utilized in studies of sovereign credit rating and credit rating of commercial banks such as research by Gültekin-Karakaş et al. (2011), Matousek and Stewart (2009), Iannotta, Nocera, and Sironi (2010), Bellotti, Matousek, and Stewart (2011a); Bellotti, Matousek, and Stewart (2011b), Caporale, Matousek, and Stewart (2012). The ordered logit model overcomes the limitation of the ordinary least-squares (OLS) model in the case of the dependent variable being credit rating levels. The limitation of the OLS model is that the difference in risk levels between 2 countries with AAA and AA rating is considered as the same as the difference in risk levels between 2 countries with $\mathrm{BBB}$ and $\mathrm{BB}$ rating. This is not consistent with the heterogeneity of differences in the level of risk between ratings (Manzoni, 2004). On the other hand, Jones, Johnstone, and Wilson (2015) also said that the ordered logit classification model is ideally suitable for studies on credit rating.

The predictive power of the ordered logit model, though, is limited when describing non-linear relationships or where unobserved fluctuations exist in the data. However, the Ordered logit model is extremely suitable for the purpose of explaining the relationship and the impact of the explanatory variable on the dependent variable (Greene, 2012).

The authors' research model used in this study is detailed as follows:

Inside:

$$
y_{i, t}=\sum_{i=1}^{m} \alpha_{i} x_{i, t-1}+\sum_{j=1}^{n} \beta_{j} x_{j, t-1}+\text { Asean }+\varepsilon
$$

$\mathrm{y}_{\mathrm{i}}, \mathrm{t}$ is the credit rating of countries in year $\mathrm{t}$.

$\mathrm{x}_{\mathrm{i}, \mathrm{t}-1}$ is a set of financial indicators indicating the macroeconomic situation of countries in year $\mathrm{t}-1$.

$\mathrm{x}_{\mathrm{j}, \mathrm{t}-1}$ is a set of indicators reflecting the ability of the government to operate the economy in year t-1.

ASEAN is the dummy variable. This variable has the value of 1 for the case of the developing countries in the ASEAN region, the value $O$ for the case of the developed countries.

\subsection{Data}

With the aim of determining the differences in the impact of factors affecting the sovereign credit ratings of developing countries in the ASEAN region and developed economies, the authors selected a sample to observe the developing countries in the ASEAN region including 5 countries Vietnam, Indonesia, Philippines, Thailand and Malaysia. The rest of the developing countries in the ASEAN region were excluded in the data sample due to the inadequacy of the data required for the study. Developed countries in the sample data include UK, USA, Canada, Italy, Australia, France, Germany, Sweden, Switzerland, Japan, Korea, and Singapore. The model's dependent variable is the sovereign credit rating of developing countries in the ASEAN region and the above-developed countries. These ratings are derived from S\&P's annual credit rating publications. The explanatory variables in the model include 2 groups of variables. The explanatory variables are the financial indicators reflecting the countries' macroeconomic situation collected from WordBank data sources. The other explanatory variables are indicators reflecting the quality of government management collected from the Worldwide Governance Indicators (WGI) 
source. Data used in the study are unbalanced table data for the period 1997 to 2019. The dependent variable is measured at time $t-1$ versus the explanatory variables because credit rating agencies assess countries' creditworthiness basing on available information of the countries's economic situation and indicators reflecting the governance capacity of the governments. The set of four macroeconomic indicators selected by the authors as the explanatory variable in the research model include GDP growth rate, inflation rate, net FDI/GDP ratio, domestic credit provided by financial sector, unemployment rate. These indicators are used in the process of evaluating the sovereign credit ratings of S\&P, Fitch, and Moody's. At the same time, these are also macro indicators used in empirical studies on countries' creditworthiness such as Cantor and Packer (1996), Mellios and Paget-Blanc (2006),Afonso, Pedro, and Philipp (2007), Jaramillo (2010),Gültekin-Karakaş et al. (2011), Tennant, Tracey, and King (2020), Sanz (2020). In addition, the authors put into the research model 6 indicators reflecting the quality of management and the ability to operate the economy of the governments. These include government voice and accountability, political stability and non-violence, government effectiveness, quality of regulation, the rule of law, and control of corruption. These are also the indicators used in researches on the credit rating of the government such as Butler and Fauver (2006), Tennant, Tracey, and King (2020).

Table-1. Descriptive statistics of the dependent variable and explanatory variables used in the research model.

\begin{tabular}{l|c|c|c|c|c}
\hline Variable & Obs & Mean & Std. Dev. & Min & Max \\
\hline Contry_Ra & 313 & 37.2364 & 13.8414 & 1.0000 & 50.0000 \\
\hline GDP & 313 & 27.7885 & 1.0908 & 25.6323 & 30.6554 \\
\hline FDI & 313 & 3.6788 & 4.8768 & -3.6203 & 28.5981 \\
\hline Inflation & 313 & 2.5950 & 3.9702 & -1.3528 & 58.4510 \\
\hline Net_Domes_Cre & 313 & 30.0317 & 2.9813 & 25.1819 & 36.5998 \\
\hline Unemploy & 313 & 5.2391 & 2.5605 & 0.2065 & 12.6828 \\
\hline Voice_Acc & 313 & 0.6769 & 0.8518 & -1.5269 & 1.7392 \\
\hline Political_Stabi & 313 & 0.4030 & 0.8322 & -2.0946 & 1.6153 \\
\hline Gover_Eff & 313 & 1.1573 & 0.7949 & -0.7053 & 2.4370 \\
\hline Regu_Qua & 313 & 1.0224 & 0.7786 & -0.7959 & 2.2605 \\
\hline Control_Corup & 313 & 0.9915 & 1.0595 & -1.1764 & 2.3256 \\
\hline Rule_Law & 313 & 1.0067 & 0.8759 & -0.9140 & 2.0378 \\
\hline
\end{tabular}

\subsection{Data Analysis Method}

To begin with, the authors regress the research model by using the Maximum likelihood regression method on table data with fixed effect and random effect to determine the explanatory variables with statistical significance in the research model. To determine the differences in the impact of the explanatory variables on the sovereign credit ratings of developed countries compared to developing countries in the ASEAN region, the authors choose the significant explanatory variables with statistical significance in the model merely built above and let each of these variables interacts with the ASEAN variable. Next, the authors regress the research model by adding interactive variable just built into the model. If the regression coefficient of the interactive variable is statistically significant, we can conclude there is a difference in the impact of the considering explanatory variable on the sovereign credit ratings of developed countries relative to other developing countries in the ASEAN region. Specifically, if the coefficient of the interactive variable has the same sign as the coefficient of the explanatory variable under consideration, the impact of this explanatory variable on the dependent variable is strengthened and more important in ASEAN developing countries. Conversely, if the coefficient of the interacting variable is contrary to the coefficient of the explanatory variable under consideration, the effect of this explanatory variable on the dependent variable decreases in the case of the developing country in the ASEAN area. This analytical method has been used in studies by Berger, Hasan, and Zhou (2010), Shen, Huang, and Hasan (2012), Mirzaei, Moore, and Liu (2013).

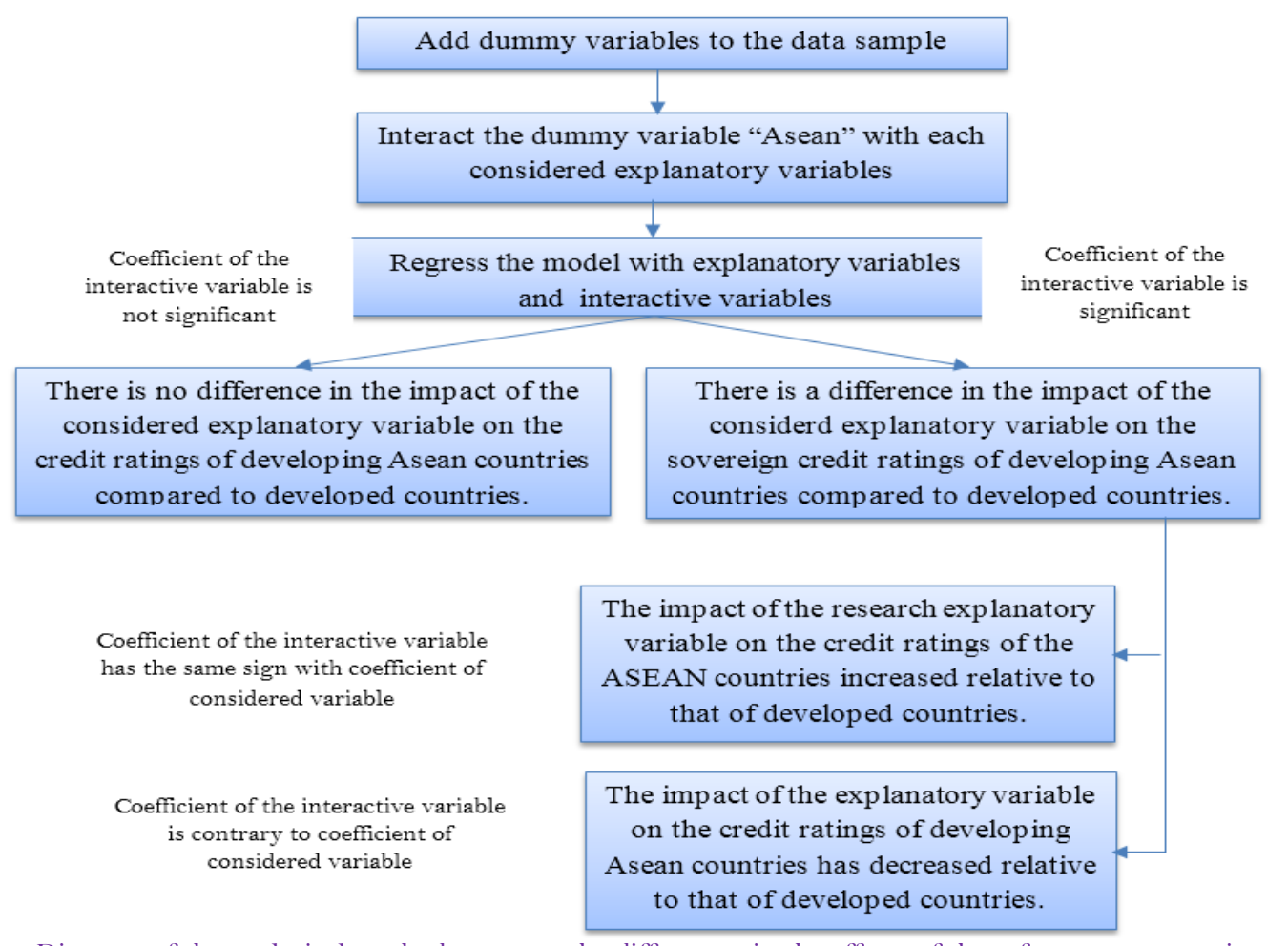

Figure-1 Diagram of the analytical method to assess the differences in the effects of these factors on sovereign credit ratings in developing ASEAN countries compared to developed countries. 


\section{Model Results and Research Results Discussion}

3.1. The Results of the Research Model

Table-2. The regression results of random - effect and fixed - effect models on sample data.

\begin{tabular}{|c|c|c|}
\hline Contry_Ra & Ordered Logit (Random - Effect) & Ordered Logit (Fixed- Effect) \\
\hline ASEAN & $\begin{array}{l}-0.5477 \\
(1.3450)\end{array}$ & $\begin{array}{l}-0.5483 \\
(0.7863)\end{array}$ \\
\hline GDP & $\begin{array}{l}0.6038^{*} \\
(0.3349)\end{array}$ & $\begin{array}{c}0.4550^{* * * *} \\
(0.1674)\end{array}$ \\
\hline FDI & $\begin{array}{l}-0.2728 \\
(0.6872) \\
\end{array}$ & $\begin{array}{c}0.0375 \\
(0.0576)\end{array}$ \\
\hline Inflation & $\begin{array}{c}-0.0689^{* *} \\
(0.0348)\end{array}$ & $\begin{array}{l}-0.0554^{*} \\
(0.0326) \\
\end{array}$ \\
\hline Net_Domes_Cre & $\begin{array}{c}-0.2685^{* *} \\
(0.1321) \\
\end{array}$ & $\begin{array}{c}-0.1961 * * * \\
(0.0753)\end{array}$ \\
\hline Unemploy & $\begin{array}{c}-0.3605 * * * \\
(0.0911) \\
\end{array}$ & $\begin{array}{c}-0.2608 * * * \\
(0.0720)\end{array}$ \\
\hline Voice_Acc & $\begin{array}{c}0.1115 \\
(0.5427)\end{array}$ & $\begin{array}{c}0.2661 \\
(0.3568)\end{array}$ \\
\hline Political_Stabi & $\begin{array}{c}0.4996 \\
(0.4878) \\
\end{array}$ & $\begin{array}{l}-0.3503 \\
(0.3120) \\
\end{array}$ \\
\hline Gover_Eff & $\begin{array}{c}0.9654 \\
(0.8496)\end{array}$ & $\begin{array}{c}0.8193 \\
(0.7234)\end{array}$ \\
\hline Regu_Qua & $\begin{array}{c}4.4468^{* * * *} \\
(1.0218)\end{array}$ & $\begin{array}{c}3.0828 * * * \\
(0.8037)\end{array}$ \\
\hline Control_Corup & $\begin{array}{l}1.6596^{*} \\
(0.8946)\end{array}$ & $\begin{array}{c}1.8031 * * * * \\
(0.6845)\end{array}$ \\
\hline Rule_Law & $\begin{array}{c}0.0569 \\
(1.1024)\end{array}$ & $\begin{array}{c}1.1046 \\
(0.8184)\end{array}$ \\
\hline $\begin{array}{l}\text { Note: } \\
\text { Total Observations: } 313 . \\
\text { * Significance at } 10 \% \text { leve } \\
\text { **Significance at } 5 \% \text { leve } \\
\text { *** Sinificance at } 1 \% \text { leve } \\
\text { Standard Errors in brack }\end{array}$ & & \\
\hline
\end{tabular}

Based on the regression results, we notice some variables representing the macroeconomic indicators that have an impact on the sovereign credit ratings. Specifically, the GDP has a positive impact on the country credit ratings. This suggests that economies with large GDP sizes are often given higher credit ratings. This result is completely similar to the results of studies on sovereign credit rating such as Cantor and Packer (1996), Eliasson (2002), Gültekin-Karakaş et al. (2011), Sanz (2020), and Criteria for rating the credit rating of credit rating agencies like S\&P, Fitch's or Moody's. On the other hand, the inflation rate and unemployment rate of countries have a negative impact on credit ratings. This result is equally consistent with the research of Mellios and Paget-Blanc (2006), Gültekin-Karakaş et al. (2011), Tennant et al. (2020). In addition, the regression results show that the size of domestic credit provided by financial sector has a negative effect on the national credit rating. The cause of this problem is that in developing countries, the credit of the commercial banking system is nevertheless considered the main capital channel in the economy due to the limited development of the stock market in these countries. Goverments of developing countries still regularly loosen the lending activities of commercial banks to create a growth engine for the economy. However, the abuse of this policy will cause many potential risks for the economy and will adversely affect the sovereign credit rating. In contrast, in developed countries, the development of the stock market has created more effective channels for capital mobilization for governments and businesses.

In the group of variables showing efficiency in state management, the authors find that the variable represents the quality of government regulation, measuring the perception of the government's ability to formulate incentive policies in the development of the private sector and the variable that demonstrates the ability to control corruption have a beneficial effect on sovereign credit ratings. This result is similar to that of Hammer, Kogan, and Lejeune (2006).

\subsection{Difference in the Impact of Factors Influencing National Credit Ratings in Developing ASEAN Countries versus Developed Countries}

As mentioned in Section 2.3, the authors add the ASEAN dummy variable to the model and make this variable interact with the statistically significant variables in the research model presented in Section 3.1. Then, the authors regress of the research model to determine the difference in the impact of each specific factor on the sovereign credit ratings of developing ASEAN countries compared to developed countries. The detailed regression results of each model are presented in Table 3.

Based on the results of the models with interactive variables, we find that the regression coefficients of the interaction variables ASEAN_GDP and ASEAN_Infla are statistically significant. Simultaneously, the coefficient sign of these two variables is opposite to the coefficient sign of the two variables GPD and Inflation. This proves there is a difference in the impact of the GDP scale and the inflation rate on the sovereign credit rating of developing and developed countries. Specifically, the impact of GDP size and inflation rate on the credit ratings of developing ASEAN countries is reduced compared to the impact of these two factors on the credit ratings of developed countries. The reason for this problem is explained by Ferri (2004) as the cost of data collection in developing countries is often higher than in developed countries and the quality of data of developing countries is often not guaranteed level of reliability. Therefore, when conducting rating assessments in developing countries, rating agencies invest less in data collection and analysis, but mainly on expert reviews. On the other hand, the 
damage to the reputation of the rating agencies in the case of a country with a high credit rating is insolvent would be greater than that of a country with a low credit ratings default on its debt obligations. Therefore, the impact of macroeconomic indicators on sovereign credit ratings in developing countries is often lower than the effect of these indicators in developed countries.

Table-3. Regression results between interactive variables in the model.

\begin{tabular}{|c|c|c|c|c|c|}
\hline \multicolumn{2}{|c|}{$\begin{array}{l}\text { Model with interactive variables } \\
\text { between GDP and ASEAN }\end{array}$} & \multicolumn{2}{|c|}{$\begin{array}{l}\text { Model with interactive variables } \\
\text { between Inflation and ASEAN }\end{array}$} & \multicolumn{2}{|c|}{$\begin{array}{l}\text { Model with interactive variables } \\
\text { between Net Domes_Cre and ASEAN }\end{array}$} \\
\hline$\overline{\text { ASEAN }}$ & $\begin{array}{c}-73.2226^{* * * *} \\
(18.8973) \\
\end{array}$ & $\overline{\text { ASEAN }}$ & $\begin{array}{l}-0.4594 \\
(1.4034)\end{array}$ & $\overline{\text { ASEAN }}$ & $\begin{array}{c}-14.6193^{* * * *} \\
(6.7374) \\
\end{array}$ \\
\hline FDI & $\begin{array}{l}-0.0655 \\
(0.0723)\end{array}$ & FDI & $\begin{array}{l}-0.0274 \\
(0.0682)\end{array}$ & FDI & $\begin{array}{l}-0.0619 \\
(0.0702)\end{array}$ \\
\hline GDP & $\begin{array}{c}2.6556^{* * * *} * \\
(0.6079)\end{array}$ & GDP & $\begin{array}{c}0.5943 \\
(0.3371)\end{array}$ & GDP & $\begin{array}{c}0.4695 \\
(0.3379)\end{array}$ \\
\hline ASEAN_GDP & $\begin{array}{c}-2.6318^{* * * *} \\
(0.6807)\end{array}$ & Inflation & $\begin{array}{l}-0.0706^{*} \\
(0.3571)\end{array}$ & Inflation & $\begin{array}{c}-0.0686^{* *} \\
(0.0346)\end{array}$ \\
\hline Inflation & $\begin{array}{c}-0.0585^{*} \\
(0.0345)\end{array}$ & ASEAN_Infla & $\begin{array}{l}0.0322^{*} \\
(0.1384)\end{array}$ & Net_Domes_Cre & $\begin{array}{l}-0.0302 \\
(0.1682)\end{array}$ \\
\hline Net_Domes_Cre & $\begin{array}{c}-0.4469 * * * \\
(0.1449)\end{array}$ & Net_Domes_Cre & $\begin{array}{l}-0.2710 \\
(0.1538)\end{array}$ & ASEAN_Net_domes_Cre & $\begin{array}{c}-0.4542^{* * * *} \\
(0.2109)\end{array}$ \\
\hline Unemploy & $\begin{array}{c}-0.3620^{*} * * \\
(0.0934)\end{array}$ & Unemploy & $\begin{array}{c}-0.3634 * * * \\
(0.1351)\end{array}$ & Unemploy & $\begin{array}{c}-0.3810^{* * *} \\
(0.0934) \\
\end{array}$ \\
\hline Voice_Acc & $\begin{array}{l}-0.1472 \\
(0.5596)\end{array}$ & Voice_Acc & $\begin{array}{c}0.0518 \\
(0.5584)\end{array}$ & Voice_Acc & $\begin{array}{c}0.1437 \\
(0.5568)\end{array}$ \\
\hline Political_Stabi & $\begin{array}{l}1.0288^{*} \\
(0.4324)\end{array}$ & Political_Stabi & $\begin{array}{c}0.5385 \\
(0.4336)\end{array}$ & Political_Stabi & $\begin{array}{c}0.5061 \\
(0.4294)\end{array}$ \\
\hline Gover_Eff & $\begin{array}{c}0.2679 \\
(0.8674)\end{array}$ & Gover_Eff & $\begin{array}{c}0.9782 \\
(0.8156)\end{array}$ & Gover_Eff & $\begin{array}{c}1.2404 \\
(0.8340)\end{array}$ \\
\hline Regu_Qua & $\begin{array}{c}4.9406 * * * \\
(1.0402)\end{array}$ & Regu_Qua & $\begin{array}{c}4.4911 \\
(0.9591)\end{array}$ & Regu_Qua & $\begin{array}{c}0.9616^{* * * *} \\
(1.0002)\end{array}$ \\
\hline Control_Corup & $\begin{array}{c}1.5777 \\
(0.8917)\end{array}$ & Control_Corup & $\begin{array}{c}1.7256^{* * * *} \\
(0.8801)\end{array}$ & Control_Corup & $\begin{array}{c}1.1604 \\
(0.9023)\end{array}$ \\
\hline Rule_Law & $\begin{array}{c}0.8605 \\
(1.1990)\end{array}$ & Rule_Law & $\begin{array}{c}0.0596^{*} * \\
(1.1051)\end{array}$ & Rule_Law & $\begin{array}{c}1.1406 \\
(0.8184)\end{array}$ \\
\hline
\end{tabular}

For the variables showing efficiency in government management, the regression model results show that the regression coefficients of the interactive variables are not statistically significant. This shows that no difference in the impact of the factors demonstrates the efficiency of governance on sovereign credit ratings in developing ASEAN countries compared to developed countries.

Table-3. Continue.

\begin{tabular}{|c|c|c|c|c|c|}
\hline \multicolumn{2}{|c|}{$\begin{array}{l}\text { Model with interactive variables between } \\
\text { Unemploy and ASEAN }\end{array}$} & \multicolumn{2}{|c|}{$\begin{array}{l}\text { Model with interactive variables } \\
\text { between Regu_Qua and ASEAN }\end{array}$} & \multicolumn{2}{|c|}{$\begin{array}{l}\text { Model with interactive variables } \\
\text { between Control_Corup and } \\
\text { ASEAN }\end{array}$} \\
\hline$\overline{\text { ASEAN }}$ & $\begin{array}{c}-\quad 0.7699 \\
(1.0769)\end{array}$ & $\overline{\text { ASEAN }}$ & $\begin{array}{l}-0.2537 \\
(1.5453)\end{array}$ & ASEAN & $\begin{array}{l}-0.2745 \\
(1.3283)\end{array}$ \\
\hline FDI & $\begin{array}{l}-0.0781 \\
(0.0671)\end{array}$ & FDI & $\begin{array}{l}-0.0712 \\
(0.0681)\end{array}$ & FDI & $\begin{array}{l}-0.0541 \\
(0.6382)\end{array}$ \\
\hline GDP & $\begin{array}{l}0.6227^{*} \\
(0.3489)\end{array}$ & GDP & $\begin{array}{l}0.6252^{*} \\
(0.3357)\end{array}$ & Lg_GDP_Va & $\begin{array}{c}0.6273^{* *} \\
(0.3265)\end{array}$ \\
\hline Inflation & $\begin{array}{c}-0.0701^{*} * \\
(0.0352)\end{array}$ & Inflation & $\begin{array}{c}-0.0686 * * \\
(0.0348)\end{array}$ & Inflation & $\begin{array}{c}-0.0749^{* * * *} \\
(0.0353)\end{array}$ \\
\hline Net_Domes_Cre & $\begin{array}{c}-0.2772^{*} * \\
(0.1392)\end{array}$ & Net_Domes_Cre & $\begin{array}{c}-0.2917^{* * * *} \\
(0.1344)\end{array}$ & Lg_Net_Domes_Cre & $\begin{array}{l}-0.2698 \\
(0.1283)\end{array}$ \\
\hline Unemploy & $\begin{array}{c}-0.3431^{* * *} * \\
(0.1225) \\
\end{array}$ & Unemploy & $\begin{array}{c}-0.3492^{* * * *} \\
(0.0915) \\
\end{array}$ & Unemploy & $\begin{array}{c}-0.3487^{* * * *} * \\
(0.0913) \\
\end{array}$ \\
\hline ASEAN_Unemploy & $\begin{array}{c}0.0352 \\
(0.1685)\end{array}$ & Voice_Acc & $\begin{array}{c}0.1138 \\
(0.5466)\end{array}$ & Voice_Acc & $\begin{array}{c}0.1604 \\
(0.5326)\end{array}$ \\
\hline Voice_Acc & $\begin{array}{c}0.0847 \\
(0.5592) \\
\end{array}$ & Political_Stabi & $\begin{array}{c}0.5657 \\
(0.4945) \\
\end{array}$ & Political_Stabi & $\begin{array}{c}0.6262 \\
(0.5038) \\
\end{array}$ \\
\hline Political_Stabi & $\begin{array}{c}0.5137 \\
(0.4928) \\
\end{array}$ & Gover_Eff & $\begin{array}{c}0.9921 \\
(0.8492) \\
\end{array}$ & Gover_Eff & $\begin{array}{c}0.9699 \\
(0.8448) \\
\end{array}$ \\
\hline Gover_Eff & $\begin{array}{c}0.9762 \\
(0.1685)\end{array}$ & Regu_Qua & $\begin{array}{c}3.6105 * * * * \\
(1.3001)\end{array}$ & Regu_Qua & $\begin{array}{c}4.5843^{* * * * *} \\
(1.0335)\end{array}$ \\
\hline Regu_Qua & $\begin{array}{c}\text { 4.4056**** } \\
(1.0403)\end{array}$ & $\underset{\text { a }}{\text { ASEAN_Regu_Qu }}$ & $\begin{array}{c}1.4844 \\
(1.4737)\end{array}$ & Control_Corup & $\begin{array}{c}0.5760 \\
(1.5479)\end{array}$ \\
\hline Control_Corup & $\begin{array}{c}1.6643 \\
(0.8974) \\
\end{array}$ & Control_Corup & $\begin{array}{c}1.4432 \\
(0.9136) \\
\end{array}$ & $\begin{array}{c}\text { ASEAN_Control_Cor } \\
\text { up }\end{array}$ & $\begin{array}{c}1.1873 \\
(1.3790)\end{array}$ \\
\hline Rule_Law & $0.0486(1.1047)$ & Rule_Law & $\begin{array}{c}0.1576 \\
(1.1162)\end{array}$ & Rule_Law & $\begin{array}{c}0.0550 \\
(1.1023)\end{array}$ \\
\hline
\end{tabular}

\section{Conclusion}

The study has demonstrated that the impact of the macroeconomic indicators on the sovereign credit ratings in developing countries decreases in comparison to the impact of factors in developed countries. The reason may arise from the limited quality of statistics and the high cost of collecting these data in developing ASEAN countries. Therefore, developing ASEAN countries looking to improve their sovereign credit ratings need to focus more on developing policies that encourage private sector growth and control corruption. 


\section{References}

Afonso, A., Pedro, G., \& Philipp, R. (2007). What hides behind sovereign debt ratings? European Central Bank Working Paper Series No. 711 .

Bellotti, T., Matousek, R., \& Stewart, C. (2011a). A note comparing support vector machines and ordered choice models' predictions of international banks' ratings. Decision Support Systems, 51(3), 682-687. Available at: https://doi.org/10.1016/j.dss.2011.03.008.

Bellotti, T., Matousek, R., \& Stewart, C. (2011b). Are rating agencies' assignments opaque? Evidence from international banks. Expert Systems with Applications, 38(4), 4206-42 14. Available at: https://doi.org/10.1016/j.eswa.2010.09.085.

Berger, A. N., Hasan, I., \& Zhou, M. (2010). The effects of focus versus diversification on bank performance: Evidence from Chinese banks. Journal of Banking छ Finance, 34(7), 1417-1435. Available at: https://doi.org/10.1016/j.jbankfin.2010.01.010.

Butler, A. W., \& Fauver, L. (2006). Institutional environment and sovereign credit ratings. Financial Management, 35(3), 53-79. Available at: https://doi.org/10.1111/j.1755-053x.2006.tb00147.x.

Cantor, R., \& Packer, F. (1996). Determinants and impact of sovereign credit ratings. Economic Policy Review, 2(2), 5-96.

Caporale, G. M., Matousek, R., \& Stewart, C. (2012). Ratings assignments: Lessons from international banks. Journal of International Money and Finance, 31(6), 1593-1606. Available at: https://doi.org/10.1016/j.jimonfin.2012.02.018.

Eliasson, A. C. (2002). Sovereign credit ratings. Research Notes, No. 02-1, Deutsche Bank Research, Frankfurt a. M.

Ferri, G. (2004). More analysts, better ratings: Do rating agencies invest enough in less developed countries? Journal of Applied Economics, 7(1), 77-98. Available at: https://doi.org/10.1080/15140326.2004.12040604.

Fitch. (2020). Sovereign rating criteria. Retrieved from: https://www.fitchratings.com/research/sovereigns/sovereign-rating-criteria-2610-2020, New York.

Greene, W. H. (2012). Econometric analysis (Vol. 7). London: Prentice Hall.

Gültekin-Karakaş, D., Hisarcıklılar, M., \& Öztürk, H. (2011). Sovereign risk ratings: Biased toward developed countries? Emerging Markets Finance and Trade, 47(sup2), 69-87. Available at: https://doi.org/10.2753/ree1540-496x4703s204.

Hammer, P. L., Kogan, A., \& Lejeune, M. A. (2006). Modeling country risk ratings using partial orders. European Journal of Operational Research, 175(2), 836-859. Available at: https://doi.org/10.1016/j.ejor.2005.06.040.

Haque, N. U., Kumar, M. S., Mark, N., \& Mathieson, D. J. (1996). The economic content of indicators of developing country creditworthiness. Staff Papers, 43(4), 688-724. Available at: https://doi.org/10.2307/3867366.

Iannotta, G., Nocera, G., \& Sironi, A. (2010). The impact of government ownership on bank's rating: Evidence from the European Banking Industry. Working Papers.

Jaramillo, L. (2010). Determinants of investment grade status in emerging markets. IMF Working Paper No. WP/10/117. Washington, DC: International Monetary Fund.

Jones, S., Johnstone, D., \& Wilson, R. (2015). An empirical evaluation of the performance of binary classifiers in the prediction of credit ratings changes. Journal of Banking \& Finance, 56, 72-85. Available at: https://doi.org/10.1016/j.jbankfin.2015.02.006.

Kiff, J., Nowak, S. B., \& Schumacher, L. B. (2012). Are rating agencies powerful? An investigation into the impact and accuracy of sovereign ratings. IMF Working Paper No. 12/23.

Manzoni, K. (2004). Modeling Eurobond credit ratings and forecasting downgrade probability. International Review of Financial Analysis, 13(3), 277-300. Available at: https://doi.org/10.1016/j.irfa.2004.02.010.

Matousek, R., \& Stewart, C. (2009). A note on ratings of international banks. Journal of Financial Regulation and Compliance, 17(2), 146-155. Available at: https://doi.org/10.1108/13581980910952586.

Mellios, C., \& Paget-Blanc, E. (2006). Which factors determine sovereign credit ratings? The European Journal of Finance, 12(4), $361-377$. Available at: https://doi.org/10.1080/13518470500377406.

Mirzaei, A., Moore, T., \& Liu, G. (2013). Does market structure matter on banks' profitability and stability? Emerging vs. advanced economies. Journal of Banking \& Finance, 37(8), 2920-2937. Available at: https://doi.org/10.1016/j.jbankfin.2013.04.031.

Mora, N. (2006). Sovereign credit ratings: Guilty beyond reasonable doubt? Journal of Banking \& Finance, 30(7), 2041-2062. Available at: https://doi.org/10.1016/j.jbankfin.2005.05.023.

Sanz, I. P. (2020). Using the European Commission country recommendations to predict sovereign ratings: A topic modeling approach. Expert Systems with Applications: X, 5, 100026. Available at: https://doi.org/10.1016/j.eswax.2020.100026.

Shen, C.-H., Huang, Y.-L., \& Hasan, I. (2012). Asymmetric benchmarking in bank credit rating. Journal of International Financial Markets, Institutions and Money, 22(1), 171-193. Available at: https://doi.org/10.1016/j.intfin.2011.08.004.

Tennant, D., \& Tracey, M. R. (2016). Sovereign debt and credit rating bias. New York: Palgrave-Macmillan.

Tennant, D. F., Tracey, M. R., \& King, D. W. (2020). Sovereign credit rating: Evidence of bias against poor countries. The North American Journal of Economics and Finance, 51, 100877. Available at: https://doi.org/10.1016/j.najef.2018.1 1.006.

Tennant, D. F., Tracey, M. R., \& King, D. W. (2020). Sovereign credit rating: Evidence of bias against poor countries. The North American Journal of Economics and Finance, 51, 100877 . Available at: https://doi.org/10.1016/j.najef.2018.11.006.

Citation: Quynh T.P. Lam; Quoc T. Nam; Khoa D. Nguyen (2021). Determining the Differences in the Impacts of Factors Affecting Sovereign Credit Rating: A Case Study of Developing ASEAN and Developed Countries. Asian Business Research Journal, 6: 1-6. History:

Received: 28 April 2021

Revised: 2 July 2021

Accepted: 26 July 2021

Published: 11 August 2021

Licensed: This work is licensed under a Creative Commons

Attribution 3.0 License $($ cc)

Publisher: Eastern Centre of Science and Education

Eastern Centre of Science and Education is not responsible or answerable for any loss, damage or liability, etc. caused in relation to/arising out of the use

of the content. Any queries should be directed to the corresponding author of the article.
Acknowledgement: All authors contributed equally to the conception and design of the study.

Funding: This study received no specific financial support.

Competing Interests: The authors declare that they have no competing interests.

Transparency: The authors confirm that the manuscript is an honest, accurate, and transparent account of the study was reported; that no vital features of the study have been omitted; and that any discrepancies from the study as planned have been explained.

Ethical: This study follows all ethical practices during writing. 